Bezerédi Imre

\title{
Biztos út..., \\ avagy gondolatok az egyes \\ rendészeti feladatot ellátók tevékenységéröl
}

\author{
The Sure Way... \\ Or Thoughts about the Activities of Certian Types \\ of Law Enforcement Employees
}

\begin{abstract}
Absztrakt
Rendőri vezetöként lehetöségem adódik folyamatos párbeszédet folytatni egyes rendészeti feladatokat ellátókkal, így mezöörökkel, természetvédelmi örökkel, halászati örökkel, állományom koordinálása útján betekinthetek tevékenységükbe és feladatkörükbe. Jelen tanulmányomban a rendörség mellett létrejött legitim rendészeti hatalommal bíró partnerek bemutatására vállalkozom egy gyakorló rendőr szemszögéböl.
\end{abstract}

Kulcsszavak: egyes rendészeti feladatokat ellátók, magyar rendőrség, rendszerváltás, együttmüködés

\section{Abstract}

As a police chief, I have the opportunity to engage in ongoing dialogue with certain law enforcement employees, such as field rangers, park rangers, fishery rangers and while

Kunszentmiklós Rendőrkapitányság, Rendészeti Osztály, r. őrnagy, osztályvezető, Nemzeti Közszolgálati Egyetem Rendészettudományi Kar, Doktori Iskola, doktorandusz - Kunszentmiklós Police Station, Law Enforcement Division, police major Head of Division, National University of Public Service, Faculty of Law Enforcement, Doctoral School, PhD student, e-mail: bezke1@gmail.com, ORCID: https://orcid.org/0000-0002-3113-0022 
coordinating the activities of my staff, to gain insight into their activities and responsibilities. In this study, I intend to introduce partners with a legitimate police force, alongside the national police, from the perspective of a practicing police officer.

Keywords: law enforcement, Hungarian police, regime change, cooperation

\section{Elöszó}

„Képes-e az adott társadalom intézményesített szervezete ellenőrzés alatt tartani a bünözést és a hivatalos társadalmi kontroll útján normálissá tenni a mindennapi életet [...]?"2 Tette fel a kérdést Szabó András 1980-ban, amikor az újkori magyar kriminológia a bűnözés tendenciájának még csupán a kisebb keletkezését tárgyalta, és mutatott rá ezzel célzottan más, a közbiztonság ${ }^{3}$ megteremtésében részt vevők szükségszerü bevonására.

A magyar rendőrségnek a rendszerváltást megelőzően kizárólagos privilégiuma volt a közbiztonság produktumának megteremtésében, amelyet egynéhány külső segitőtől eltekintve kifejezetten zárt közegben végzett. A rendszerváltás idejében megjelenő jogszabályok (például az egyesülési jogról szóló 1989. évi II. törvény) és ezzel együtt a bűncselekmények növekvő száma ösztönözte a lakosságot önvédelmi civil szervezetek, mint a polgárőrség, mára a rendőrség legfőbb stratégiai partnereként emlegetett szövetséges szervezet megalakítására. A civil szervezetek hatékonysága azonban nem pusztán a hatósági jogkörökkel való felruházáson és azok gyakorlásán múlik, hanem a közigazgatás más szereplőin is. A rendőrség 1949 óta „a centralizált, katonai elvekre épülő, a civil közigazgatástól elkülönülő államrendőrségi modellként"4 szerveződött, és a decentralizációs folyamat a rendszerváltást követően sem vette kezdetét, szükség volt valamilyen módon lokális alapokra helyezni a közbiztonság megerősítését. Az egységes közbiztonsági stratégiát mellőző politikai színtér az új, 2011. évi önkormányzati törvénnyel nyitott a decentralizálás felé.

\section{Szükségszerüségek}

A decentralizálás kapcsán térjünk ki előbb a szó jelentésére. A Révai testvérek lexikonjukban a centralizációt mint politikai műszót jelölték, ami azt a rendszert jelenti, amelyben a mozgató erő a központi főszerv, és tőle indul ki minden müködés. „Ellentéte

\footnotetext{
Szabó András: Bünözés - ember - társadalom, Közgazdasági és Jogi Könyvkiadó, Budapest, 1980, 138.

A modern európai felfogás szerint a közbiztonság olyan kollektív társadalmi termék, amely az egyének és közösségeik tevékenységéből, az állami szervek hatósági intézkedéseiből, a polgárok önvédelmi képességei és a vállalkozói piac nyújtotta szolgáltatások együtteséből alakul ki. Ennek mérésére, elemzésére a fejlett demokráciákban egyre bonyolultabb és pontosabb módszereket alkalmaznak. Ilyenek például az áldozatok megkérdezésén vagy a lakosság széles köreiben végzett vizsgálatok eredményein alapuló elemzések. Nálunk ezek még nem részei az intézményesen szervezett tájékoztatásnak, ilyen típusú információk nem állnak a jogalkotó rendelkezésére. 115/2003. OGY határozat a bủnmegelőzés nemzeti stratégiájáról.

Finszter Géza: Rendészetelmélet, Nemzeti Közszolgálati- és Tankönyvkiadó, Budapest, 2014, 58.
} 
a decentralizáció. ${ }^{15} \mathrm{~A}$ decentralizáció segítené a helyi rendőrt az adott településen sürgető ügyeket megfelelő szinten és diszkrecionális jogával megfelelően élve ellátni. Egyfajta kapocs a körzeti megbízotti szolgálat is, mint a „közösségi rendőrséghez"6 vezető út kezdeti határköve, azonban mint beosztott más székhelyi településű rendőrőrshöz vagy kapitánysághoz tartozása által sajnos máris elszakítjuk a fenti előnyöktől. Példaként említeném meg a főként a szervezet centralizáltságát és ezáltal a rendfenntartó tevékenységét erősítő Tevékenységirányító Központok ${ }^{7}$ felállítását is, amelyek esetenként a gyorsabb reagálás érdekében más illetékességű, közelebb lévő rendőrt irányítanak egy-egy bejelentéshez, olykor annak pontosabb tartalmi megvizsgálása nélkül. Emellett a helyi szinteken elismert közösségi rendőri feladatokat is ellátó körzeti megbízottak tevékenységét szabályzó 20 éves ORFK-normának felváltása által az új szabályzó a körzeti megbízottakat szigorúan a településére, körzeti megbízotti csoportjába utalja, onnan történő elvonása szigorú szabályokhoz kötött. ${ }^{8}$ Történt próbálkozás a körzeti megbízotti szolgálat közösségi rendőri modellé történő kialakítására. Ennek során az úgynevezett "Svájci Alapból" támogatott modellkísérletet négy városban vezették be: Miskolcon, Nyíregyházán, Szegeden és Zalaegerszegen. „A Svájci-Magyar Együttmüködési Programnak köszönhetően 476 millió forint svájci támogatás tette lehetővé, hogy az azt kiegészítő magyar támogatással együtt 2012 és 2016 között mindösszesen 560 millió forint felhasználásával Miskolcon, Nyíregyházán, Szegeden és Zalaegerszegen lehetőség legyen a közösségi rendészet modelljének alkalmazásszintű kipróbálására.

A Belügyminisztérium, az Országos Rendőr-főkapitányság, valamint az érintett megyei rendőr-főkapitányságok részvételével megvalósított projekt célja az volt, hogy a rendőrség a helyi közösségek tagjaival közösen azonosítsa a közbiztonsági problémákat, és az azok feloldására vonatkozó megoldások kidolgozásába és végrehajtásába nagyobb mértékben vonja be a lakosságot. A közösségi rendészet filozófiája alkalmas lehet arra, hogy a rendőrkapitányságok hatékonyabban, a közösség igényeinek megfelelőbben használhassák fel erőforrásaikat. A projektben részt vevő állomány képzését követő egy évben került sor annak elemzésére, hogy a közösségi rendészet

\footnotetext{
„A koncentráció és a dekoncentráció, illetve a centralizáció és a decentralizálás összekapcsolása a modern államigazgatás számára elsődlegesen szakmai feladat. Vannak világos rendező elvek, amelyek alapján eldönthető, hogy egy hatósági feladatot mikor célszerü a központban megtartani, illetve mikor indokolt az önkormányzati közigazgatáshoz delegálni." Finszter Géza: A rendőrség joga, Duna Mix Kft., Budapest, 2012, 251.

6 „A magyar származású amerikai rendészetkutató, Robert R. Friedmann meghatározása szerint: „A közösségi rendőrség olyan irányvonal és stratégia, amely a bűnözés kontrolljának eredményesebbé és hatékonyabbá tételét, a bűnözéstől való félelem csökkentését, az életminőség javítását, a rendőri szolgáltatások és a rendőrség elfogadottságának magasabb szintre emelését célozza a közösségi forrásokra építő proaktív müködéssel, a bünözést keletkeztető körülmények megváltoztatása útján. Feltételezi a rendőrség megnövekedett felelősségét, a közösség nagyobb arányú részvételét a döntéshozatalban, továbbá fokozott figyelmet az alapjogok és a polgári szabadságok érvényesülése iránt." Korinek László: Rendszerváltozás a belügyben, Belügyi Szemle, 63 (2015/1) 14

Az általános rendőrségi feladatok ellátására létrehozott szerv tevékenységirányítási központjai, egyes rendőri szervek ügyeletei, valamint a segélyhívásokat fogadó központok egységes müködéséről szóló 57/2013. (XII. 21.) ORFK utasítás 64. pontja alapján a TIK Ügyeletesek az eseményekre történő reagálást, az irányított állomány küldésének sorrendjét, az igénybe vett erö-eszköz mennyiséget a folyamatban lévő eseményt folyamatosan mérlegelve határozzák meg.

8 A körzeti megbízotti szabályzatról szóló 26/2015. (XII. 9.) ORFK utasítás 21. pontja alapján „a körzeti megbízott a körzeti megbízotti működési körzetéből eseti jelleggel kizárólag: a) a személyi állomány értesítése (riadó elrendelése) esetén; b) fokozott ellenőrzés elrendelése esetén; c) különleges jogrend alkalmával; d) különösen indokolt, késedelmet nem türő rendőri intézkedés (az élet, testi épség, vagyonbiztonság veszélyeztetése) esetén; e) csapatszolgálati tevékenység végrehajtása esetén vonható el."
} 
eszközrendszere - amelyet már több évtizede alkalmaznak többek között Svájcban, az Egyesült Királyságban és az Amerikai Egyesült Államokban- mennyiben tudja kiegészíteni a hagyományos magyar rendőrségi modellt, eljárásrendeket. A rendőrkapitányságok kijelölt munkatársai egyebek mellett fogadóórák, bűnmegelőzési előadások megtartásával járultak hozzá az állampolgárokkal való közvetlenebb kapcsolat kialakitásához, a rendőrség és a polgárok közötti bizalom megerősödéséhez. A projekt záró rendezvényének résztvevői bemutatták és értékelték a tapasztalatokat és az elért eredményeket." ${ }^{\prime 9} \mathrm{~A}$ pilot keretében önkéntes jelentkezés alapján 40 fő körzeti megbízott részesült továbbképzésben a community policing terén, azonban a projekt kommunikációja nem volt alapos az érintett állomány felé. A kollégák szóbeli elmondásuk alapján föként a bizonytalanságok miatt nem mertek jelentkezni. Féltek, hogy a pilot további elvonást fog eredményezni alapfeladatuktól, és féltek a további leterheltségtöl is. A pilotba bevont településeken kialakított körzetekben körülbelül 15 ezer állampolgárra jutott egy közösségi rendőr. Ennek kapcsán a közrendvédelmi tapasztalattal rendelkező szakértők aggályosnak nevezték és előre jelezték, hogy ilyen magas lakosságszám esetében csak korlátozottan lehet eredményes a közösségi rendör tevékenysége..$^{10} \mathrm{~A}$ community policing az angolszász országokban ${ }^{11}$ bevezetett rendőrségi modell, amely természeténél fogva nélkülözi a centrálisan müködő rendőrség elveit. A korábban említett programba bevont körzeti megbízottak függetlenítve voltak más feladatoktól, azonban meggyőződésem, hogy a magyar rendőrségben szocializálódott, statisztikai szemlélettel felvértezett reaktív szemléletű rendszerben hosszú távon lehetetlen lett volna az átállás. Mindezt nehezítették a 2015-re kicsúcsosodó illegális migráció, a folyamatos elvonó tényezők, mint például területi vagy országos szintű biztosítási feladatok, akciók vagy éppen az EU fehér könyve által sürgetett közlekedésrendészeti helyzet javítása kapcsán felmerülő kötelezettségek. A körzeti megbízotti állomány ugyanis - eredendően saját körzetében - de felelös a fentiekért is.

Talán az egyik legjobb megoldás az önkormányzati rendőrségek létrehozása lenne, azonban annak megteremtése a jelenlegi szervezeti struktúra mellett már nem biztos, hogy praktikus. Egyesek szerint (Boros Péter, Team Consult) szakmai érdekek, mint egységes nemzeti rendőrség müködtetése, mások szerint (Finszter, Salgó) a politikai hatalom gyakorlásának készsége, de az bizonyos, hogy az 1990. októberi taxis blokád és annak kezelése (vagy inkább kezelési csődje) világított rá a decentralizálás mellett álló Antall-kormány politikájának kontraszelekciójára, és győzte meg a hatalmat a centrális, erősen központi vezetésű magyar rendőrség fenntartására, még ha ezt ekkor más külső okokkal (például délszláv háború) indokolták is.

Az állami rendőrség és a piaci alapon müködő magánbiztonsági cégek dichotómiája mellett harmadik útnak szokták nevezni a közösségi rendészetet, amely az erősen hierarchizált és társadalomtól elszakadt rendőrséget felváltva a lakossággal történő

Közösségi Rendészeti Projekt, 2016, www.police.hu/hu/a-rendorsegrol/europai-tamogatasok/egyeb-forrasok/kozossegirendeszeti-projekt (Letöltve: 2019. 11. 13.)

10 Búzás Gábor hozzászólása a Rendészetelméleti Kutatómühely, A közösségi rendészet hazai perspektívái címmel 2013. 10. 16-án, az NKE RTK-n megtartott szakmai konferencián.; Christián László: Egy feledésbe merülő közösségi rendészeti modellkísérlet margójára, in: Gondolatok a Rendészettudományról. Írások a Magyar Rendészettudományi Társaság megalapításának tizenötödik évfordulója alkalmából, Magyar Rendészettudományi Társaság, Budapest, 2019, 84

11 A community policing modellt elsőként müködtető országok az Egyesült Királyság, az USA és Kanada. 
együttmüködésre helyezi a hangsúlyt.12 Más kérdésként vetődik fel a finanszírozás, miszerint kisebb települések kevesebb anyagi háttérrel indulnának a közbiztonság mint produktum megteremtésében, és ugyancsak következő kérdés a helyi politikai érdekek lokális jellegü rendészeti szerv általi képviselete. Az Alaptörvény elszakította ugyan a rendészeti feladatokat a honvédelemtöl, közelebb helyezve ezáltal azt a közigazgatás színterére, azonban a Helyi Önkormányzatok Európai Chartájáról szóló 1985. október 15-én kihirdetett (hazánkban az 1997. évi XV. törvénynél becikkelyezett) európai egyezményben foglaltak, miszerint „a közfeladatokat általában elsősorban az állampolgárokhoz legközelebb álló közigazgatási szervnek kell megvalósítania."13 az új önkormányzati törvény által mégsem teljesültek be.

Legyen szó közösségi rendőrségről, ${ }^{14}$ avagy problémaorientált rendőrségröl, az adott közösség hatványozottabban magáénak tekinti a rendőrt és már nem csupán lakhely szerinti, hanem szervezeti hovatartozása miatt is. Az önkormányzati rendőrség létrejöttének igencsak távlati (legalább 10-15 év) lehetőségei lennének egy esetleges radikális kormányzati döntés útján, azonban az egyes rendészeti feladatokat ellátók létszámának és jogkörének bővítésére nagyobb esély mutatkozik.

\section{Törvények tükrében}

A Magyarország helyi önkormányzatairól szóló 2011. évi CLXXXIX. törvény (a továbbiakban: Mötv.) 13. § (1) bekezdésének 17. pontja szerint az önkormányzat közremüködik a település közbiztonságának biztosításában. Az új önkormányzati törvény által az önkormányzatok lehetőséget kaptak a 17. § rendelkezései szerint, hogy „(1) [...] a helyi közbiztonságról, vagyonának, más értékének védelméről kényszerítő eszköz alkalmazására törvény alapján jogosult szervezet létrehozásával is gondoskodhat. (2) $\mathrm{Az}$ (1) bekezdésben meghatározott szervezet alaptevékenységét a települési és a fővárosi önkormányzat területe szerint illetékes megyei (fövárosi) rendőr-fökapitánysággal kötött írásbeli együttmüködési megállapodás alapján, a rendőrség szakmai felügyeletével végzi. [...] (3) Az (1) bekezdésben meghatározott szervezet által végezhető feladatokat, az alkalmazható kényszerítő eszközöket, az együttműködési megállapodásra, valamint a szervezet múködésére vonatkozó szabályokat, továbbá az e feladatokat ellátókkal szemben támasztott személyi feltételeket törvény határozza meg. (4) E § rendelkezéseit alkalmazni kell akkor is, ha az önkormányzat az (1) bekezdésben meghatározott feladatokról nem önálló szervezet létrehozásával gondoskodik."15

12 Christián László: Az önkormányzati rendörség és a közösségi rendészet összefüggéseiröl, in: Kákai László (szerk.), 20 évesek az önkormányzatok, Publikon Kiadó, Pécs, 2010, 423-426.

13 1997. évi XV. törvény A Helyi Önkormányzatok Európai Chartájáról szóló, 1985. október 15-én, Strasbourgban kelt egyezmény kihirdetéséröl 4. cikk 3. bekezdés.

14 „Robert Friedmann kifejezetten ajánlotta a rendszerváltás utáni Magyarországon is a közösségi rendörség értékeinek meghonosítását (Friedmann 1996, 122-123.). Bólyai János a rendőrség és a társadalom viszonyával foglalkozó kandidátusi értekezésében megállapítja, hogy az új típusú rendőri működésnek nálunk nincs meg minden előfeltétele, a fejlesztés irányának kijelölésében azonban egyértelmüen a közösségi rendőrség értékeit kell alapul venni (Bólyai, 1994)..." Korinek László: Nomádok és letelepedettek - gondolatok a közösségi bűnmegelőzésről, Jogtudományi Közlöny, 61 (2006/7-8) 261.

15 2011. évi CLXXXIX. törvény Magyarország helyi önkormányzatairól. 
Következő mérföldkő a decentralizálás felé vezető jogszabályi környezet kialakításában az egyes rendészeti feladatokat ellátó személyek tevékenységéröl, valamint egyes törvényeknek az iskolakerülés elleni fellépést biztosító módosításáról szóló 2012. évi CXX. törvény (a továbbiakban: ERFSZ-törvény) volt. Az ERFSZ-törvény egyszersmind rendészeti feladatokat ellátóknak kiáltotta ki a természetvédelmi őrt, az erdővédelmi szolgálat tagját, a hegyőrt, a hivatásos vadászt, a rendészeti feladatokat ellátó erdészeti szakszemélyzetet, a rendészeti feladatokat ellátó jogosult erdészeti szakszemélyzetet, a halászati őrt, a közterület-felügyelőt, az önkormányzati természetvédelmi őrt és a mezőőrt. Részben a formaruha viselését, az általuk foganatosítható intézkedések, kényszerítő eszközök alkalmazásának és személyes szabadságot korlátozó intézkedések lehetőségeit, azok kivizsgálását és az együttműködés rendjét szabályozza. Az egyes rendészeti feladatokat ellátók létszáma folyamatosan emelkedik, 2019-re vélhetően a 10 ezer föt is meghaladják. Az egyes rendészeti feladatot ellátó személy így válik az önkormányzatok által a helyi közbiztonság megteremtésében kulcsfontosságú és több ízben hatáskörrel egyedül rendelkező szereplőjévé a közbiztonság mint társadalmi termék megteremtésében.

\section{A rendőrség és a rendészeti feladatokat ellátók együttmü- ködése a Bács-Kiskun Megyei Rendőr-fökapitányság aspek- tusából}

„Annak köszönhetően, hogy a mai magyar rendőrség nemcsak bünfelderítő, prevencionáló és bűnüldözési feladatokat lát el, hanem valóban a közösség érdekében, a biztonság megteremtéséért a nap 24 órájában fáradozik, látható eredményt ér el: a magyar lakosok és az országban tartózkodó polgárok biztonságban érezhetik magukat. Mindezt úgy érte el, hogy az Alaptörvényböl és különböző jogszabályokból levezethető társadalmi érdekek és értékek védelmét megteremtette. Ha a helyi illetékességủ szervek vonatkozásában mérnénk mindezt, akkor is jól látható, hogy az alapfeladatok mellett - helyi szinten, akárcsak központi és területi szinten is - a segítő szándék és a szolgáltató jelleg mennyire jelen van. A rendőrség általános feladata és a klasszikus vezetési rendszer alapján meghatározott feladatszabás, információgyüjtés, elemzés, értékelés és célmeghatározás nem különül el. A generális céloknak minden szervezet és szervezeti egység maximálisan megfelel."16

A rendőrség és az egyes rendészeti feladatot ellátó személyek és munkáltatóik közötti együttmüködés településenként, járásonként és megyénként is egészen biztosan eltérő. Az általam ismert és koordinált Kunszentmiklós Rendőrkapitányság fenti szereplőkkel történő együttmüködése nagyban illeszkedik a Bács-Kiskun Megyei Rendőr-főkapitányság (a továbbiakban: BKMRFK) által képviselt profilba,

\footnotetext{
Kovács István: Vezetési funkciók egy helyi rendvédelmi szerv életében-célmeghatározás, vagyis a feladatok kitűzésének, és tisztázásának folyamata, Rendőrségi Tanulmányok, 1 (2018/3) 134.
} 
mint ahogyan a centrális alapokon szervezett magyar rendőrség irányítási elve (fayoli alapelv mentén) ${ }^{17}$ megköveteli.

A közös feladatellátás egyes helyi szerveknél nehézségekbe ütközik, bár a települések fekvéséből és jellegéből adódóan a rendészeti feladatot ellátó személyek működésével kapcsolatban eltérő igények mutatkoznak. A közös szolgálatokat a közrendvédelmi/rendészeti osztályvezetők és az őrsparancsnokok közvetlen irányítása mellett az alosztályvezetők és a körzeti megbízottak szervezik heti rendszerességgel. Az egyes rendészeti feladatokat ellátó személyekkel történő kapcsolatfelvétel legjelentősebb hozadéka az információáramlás.

Több bűncselekmény elkövetőjét is rendészeti feladatokat ellátó személyek segítségével fogják el. A külterületi közös járőrözés mellett a rendezvénybiztosításokban is tevékeny szerepet vállalnak, ezzel is segítve a rendőrség munkáját. A kiemelkedő szakmai intézkedések, így szabálysértési- és büntetőfeljelentések, elfogások és előállítások magasabb számban is figyelhetők meg azon jogsértések tárgyában, amelyekhez sajátos szakterületi ismeret szükségeltetik. A közös szolgálatok ellátása nem nevezhető sablonosnak, azok mindig célhoz kötöttek, biztosítják a bevont rendőri erők hatékony kihasználását.

A rendőrkapitányságok és a munkáltatók között folyamatos írásbeli és szóbeli kommunikáció zajlik, azonban a szakmai fejlődés elősegítésére főként a közös szolgálatok és az azokat megelőző eligazítások szolgálnak. A szervezett és végrehajtott közös szolgálatok értékelésére változóan, általában havi rendszerességgel kerül sor a közrendvédelmi (rendészeti) osztályvezetők/őrsparancsnokok által személyesen, vagy akadályoztatás esetén telefon útján. Nagyobb volumenü akciók szervezésekor közvetlenül annak befejeztével megvalósul az együttműködés értékelése. Az értékelések alkalmával minden esetben előirányozzák és megszervezik a további közös szolgálatokat. Az egyes rendészeti feladatokat ellátó személyekkel, szervezetekkel teljesített közös szolgálatok az elmúlt évek tapasztalatai alapján folyamatosan fejlődő szolgálatszervezési rendszer útján folyamatosak. A közösen ellátott szolgálatok során a kölcsönös intézkedési aktivitást és felkészültséget jellemzi a megfelelő arányú intézkedési mutató, a lefolytatott intézkedések jog- és szakszerüsége, az illetékességi területen történő magasabb óraszámú jelenlét.

A szervek vezetőivel, tagjaival a kapcsolattartás napi szinten müködik, aminek köszönhetően a közös szolgálat szervezése igazodik a szervek napi feladataihoz, az aktuálisan felmerülő problémákhoz, igényekhez. Ennek köszönhetően a közös szolgálatok ellátása nem válik sablonossá, azok mindig célhoz kötöttek, biztosítják a bevont rendőri erők hatékony kihasználását. A törvényben meghatározott rendészeti feladatokat ellátó szervekkel történő közös értékelők megtartására éves szinten kerül sor. Ezen értékelők során tett közös kinyilatkoztatások alapján mind a rendőrkapitányságok, mind a munkáltatók részéről kölcsönösen konstatálható, hogy az együttmúködés jól teljesül.

17 „A centralizáció és decentralizáció mértéke - az alárendelteknek biztosított cselekvési szabadságuknak és döntési jogkörüknek összhangban kell lennie a felelösséggel; a beosztottak kapják meg a munkájuk elvégzéséhez szükséges hatáskört, de a felelősség a vezetőké. Az alárendeltek szerepének csökkenése a döntéshozatalban centralizációt, szerepük növelése decentralizációt eredményez, amely mérték függvénye a szervezeti alkalmazásból eredően; [...]" Kovács Gábor - Czuprák Ottó: A szervezetvezetés elmélete, Budapest, Dialóg Campus, 2017, 51. 
A rendészeti feladatokat ellátó személyek száma bár egyre növekszik, nem minden településen teljesítenek szolgálatot. A közös feladatellátás egyes helyi szerveknél nehézségekbe ütközik, bár a települések fekvéséből és jellegéből adódóan a rendészeti feladatot ellátó személyek múködésével kapcsolatban eltérő igények mutatkoznak.

Az ERFSZ-törvény hatálybalépésétől 2015. december 31-éig a Bács-Kiskun Megyei Rendőr-főkapitányság 45 együttmüködési megállapodást kötött az egyes rendészeti feladatokat ellátó személyek munkáltatóival. A Bács-Kiskun Megyei Rendőrfőkapitányság illetékességi területén a 2012. évi CXX. törvény hatályba lépése óta a rendészeti feladatokat ellátó személyek ellen hatóságunkhoz panasz nem érkezett.

Az érintett személyi körhöz tartozó közremüködők részére évente egy alkalommal megvalósul az elméleti és gyakorlati képzés, amelynek célja a jogszerübb, szakszerűbb és hatékonyabb együttmüködés. Ennek során a rendőrök és a rendészeti alkalmazottak a gyakorlati végrehajtáson túl további szakmai kérdéseket tesznek fel egymásnak, megismerik ezáltal azokat a tapasztalatokat és módszereket, amelyek révén célravezető intézkedések foganatosíthatók.

A rendőrség egyik fö célkitűzése, hogy a lakosság biztonságérzetének megörzése, illetőleg javítása érdekében a lehető legszélesebb körben használja ki az egyes rendészeti feladatokat ellátó személyekben, valamint az általuk képviselt erö- és eszközpotenciálban rejlő lehetőségeket. A körzeti megbízotti szabályzatról szóló 26/2015. (XII. 9.) ORFK utasítás alapján a körzeti megbízottak éjszakai szolgálatteljesítésre egyedül nem oszthatók be, így elengedhetetlenül szükséges a rendészeti feladatokat ellátó személyek eddigieknél is fokozottabb bevonása a közterületi szolgálatba.

\section{„Egyesek" a rendészetben}

Az alábbi fejezetben bemutatom egy területi szerv rendészeti szakmai állásfoglalását az egyes rendészeti feladatot ellátók fentebb tárgyalt sajátos szakterületi ismeretével kapcsolatban.

A hely- és személyismeretüknek köszönhetően a lakcímkutatások, elővezetések, a körözött személyek tartózkodási helyének megállapítása során több esetben szolgáltattak releváns információt a mezőőrség munkatársai. A mezőőrökkel folytatott közös járőrszolgálatok célja a termőterületeken elkövetett jogsértések, így elsősorban a terménylopások megakadályozása, az elkövetők tettenérése.

A BKMRFK illetékességi területén található a Gemenc Zrt. szekszárdi, illetve hajósi erdészeteinek, továbbá a Duna-Dráva Nemzeti Park területének egy része is. Ennek köszönhetően illetékességi területünk vadban, halban és erdőben is kiemelkedően gazdag. E természeti kincsek megőrzése érdekében a külterületeken szolgálatot teljesítő körzeti megbízottak a vadőrökkel, hivatásos vadászokkal, halászati örökkel és a természetvédelmi örszolgálat munkatársaival teljesítettek közös szolgálatot. A közös szolgálatok alkalmával járörszolgálat keretében ellenőrizték a védett szárazföldi, illetve vízzel borított területeket, figyelőszolgálatot hajtottak végre az orvvadászok, illegálisan halászatot folytatók tettenérése céljából. A vadőrökkel folytatott közös ellenőrzések során illegális vadcsapdákat és azok telepítését elvégző elkövetőket találtak meg, majd fogtak el, valamint segítségünkre voltak kábítószerrel kapcsolatos 
büncselekmény kapcsán az elkövetők felkutatásának érdekében végzett terepkutatáskor is. A halászati őrök és hivatásos vadászok rendelkeznek azon információkkal, amelyek elősegítik a helyi rendőrök (főként körzeti megbízottak) által fokozottabb ellenőrzést igénylő területek és azok sajátosságainak megismerését, az egyes halak és vadak elejtésének módszereit, szokásait, az elkövetéshez használt eszközöket. Nem véletlenül tartanak folyamatosan a BKMRFK több rendőrkapitányságán olyan oktatással egybekötött fórumot, ahol a felek (rendörök és rendészek) egymás oldaláról világítanak rá több gyakorlati és szakmai fogáson túl olyan eljárási módszerekre, specifikumokra, amelyek a közös elméleti és gyakorlati párhuzamok mentén közelebb viszik mindkét oldalt a jogsértések eredményesebb megakadályozásának, felszámolásának irányába.

A természetvédelmi őrökkel folytatott közös feladatellátás célja a védett területek ellenőrzése, a védett növény- és állatfajok megóvása, a védett területeken az illegális hulladék elhelyezésének megelőzése. A közös járőrszolgálatokat főként azon körzeti megbízottak látják el, akik kiemelkedő hely- és személyismerettel rendelkeznek a frekventált védett területeken.

Az erdészeti szakszemélyzet munkatársaival föként a téli időszakban lát el a rendörség közösen szolgálatot. Az erdészeti felügyelet - például KEFAG Zrt. - munkatársaival rendszeresen közös „erdészeti akciót” hajtunk végre. Az együttmüködések alkalmával a bűnmegelőzés mellett lehetőség nyílik a terület sajátosságainak megismerésére és az információk cseréjére is. Ezen alkalmak lehetőséget biztosítanak arra, hogy a részt vevő állomány kiemelt figyelmet fordítson az illegális fakitermelések megelőzésére, felszámolására. Folyamatosan ellenőrzik területükön a fakivágások jogosságát, a kitermelt és lerakott fákat. Az erdőben és az erdőket megközelítő útvonalakon lakók figyelmét felhívják a falopások gyakoriságára, valamint arra, hogy mindennemü faáruszállítást kísérjenek figyelemmel.

A Közterület-felügyelet munkatársaival elsősorban piacok, vásárok alkalmával látunk el közös szolgálatot, de bevonjuk őket a lakótelepek tisztaságának megóvása, a városközpontokban szabálytalanul parkoló gépjármüvek kiszűrése érdekében, valamint a külterületeken történő illegális hulladéklerakás megakadályozásának céljából. Fontos kiemelni, hogy a közterület-felügyelők, hasonlóan a polgárőrszervezetek tagjaihoz, rendszeresen vesznek részt a rendezvények biztosításában, az árvízi védekezésben, ahol területlezárásokban, forgalomterelésekben segítették a feladat végrehajtásába bevont rendőri erők munkáját.

\section{Összegzés}

„És minél inkább centralizált a szervezetük, a helyi bajokkal szemben annál tehetetlenebbek. A centralizált szervezet erőinek legnagyobb részét központi feladatokra kénytelen koncentrálni, miközben elveszíti helyismeretét és kapcsolatait azokkal a kis közösségekkel, amelyek a helyi közbiztonság hiányát érzékelik. A centralizált szervezet a kényszer alkalmazására összpontosít, és szinte tehetetlenné válik akkor, amikor szolgáltató, támogató funkcióit kellene teljesítenie. Ennek következtében minden akcióját a gyanakvás és a titkolózás szövetébe burkolja, a bünüldözés logikájának megfelelően 
gyanakszik a társadalomra ahelyett, hogy együttmüködne vele." ${ }^{18}$ Így fogalmaz Finszter Géza, amikor a rendőrséget mint önáló rendészeti közeget említi a közbiztonság mint produktum szavatolásakor, majd gondolatát tovább folytatva négy kriminálpolitikai „próbálkozást” említ. Elsőként a Polgárőrséget, másodikként a rendészeti feladatokat ellátó személyek legitim fizikai erőszakkal történő felruházását, ${ }^{19}$ harmadikként a rendőri szervek és egységek dekoncentrált módú szervezését és negyedikként a máig utópiának számító önkormányzati rendőrséget. A Polgárőrség és a rendőrség összefogása rávilágított arra, hogy a közbiztonság minősége ténylegesen függ a kooperációtól. Biztos lehet-e az út, amelyet a rendőrség mint a közbiztonság legnagyobb szolgáltatója egy lassan már megszokott, de mégis újnak számító professzionális társsal jár be? Az elért eredményeket, összhangot és a rendészet sokszínűvé tételét elhozó együttmüködés konstatálja az eredményt. Ez a kooperáció az elért eredményeken, kiaknázatlan fejlődési lehetőségeken túl komplex szakmai fejlődésre, speciális partnerségre és nyitásra ösztönöz. Ezenfelül legfőbb érdeme, hogy a korábban kialakult szinergia begyakorolt mechanizmussá válása tovább nyithat a rendőrség civilesítése felé annak konkrét megvalósítása nélkül. Az egyes rendészeti feladatot ellátók - a fokozott büntetőjogi védelmüket vagy akár hivatástudatukat figyelmen kívül hagyva - máig civilek maradtak a rendörökkel szemben, ami ugyancsak egy kapocs vagy akár egy kulcs lehet a rendörség és a közösségek párbeszédeinek dotációja terén.

\section{Felhasznált irodalom}

Búzás Gábor hozzászólása a Rendészetelméleti Kutatóműhely, A közösségi rendészet hazai perspektívái címmel 2013. 10. 16-án, az NKE RTK-n megtartott szakmai konferencián. Christián László: Egy feledésbe merülő közösségi rendészeti modellkísérlet margójára. Gondolatok a Rendészettudományról. Írások a Magyar Rendészettudományi Társaság megalapításának tizenötödik évfordulója alkalmából, Magyar Rendészettudományi Társaság, Budapest, 2019, 79-88.

Christián László: Az önkormányzati rendőrség és a közösségi rendészet összefüggéseiröl. In: Kákai László (szerk.): 20 évesek az önkormányzatok, Publikon Kiadó, Pécs, 2010. Christián László - A rendészet alapvonalai, Önkormányzati rendőrség, UniversitasGyör Nonprofit Kft., Győr, 2011.

Finszter Géza: A rendőrség joga, Duna Mix Kft., Budapest, 2012.

18 Finszter Géza: Rendészettan, Dialóg Campus Kiadó, Budapest, 2018, 273.

19 „A második kísérlet az önkormányzati fenntartású közterület-felügyeletek megerösítése, illetve az olyan formációk felújítása, mint a mezőör, hal- és vadörök intézménye. A közterület-felügyeletet önkormányzati irányitású szakrendészetnek tekinthetjük, e testület azonban egyes speciális (a helyi közbiztonság védelmét szolgáló) hatásköröket gyakorol, és rendészeti kényszerintézkedéseket csak szük körben és csak a rendörség felügyelete mellett alkalmazhat. Ha korlátozott mértékben is, de társadalmi rendeltetése a helyi közrend és közbiztonság védelme. További következtetés, hogy a szabálysértési birságoláson túl, igaz, csak módjával, de a legitim fizikai erőszak fogalma alá vonható kényszerintézkedések alkalmazására is jogosult. Erre figyelemmel a közterület-felügyelet a települési önkormányzatok irányitása alatt müködö rendészeti szerv, amelyik egyes rendészeti feladatokat a legitim eröszak monopóliumának birtokában teljesít. A másodiknak jelzett kisérlet terméke a korábban már ismertetett 2012. évi CXX. törvény is." In: Finszter Géza: Rendészettan, Dialóg Campus Kiadó, Budapest, 2018, 273-274. 
Finszter Géza: Rendészetelmélet, Nemzeti Közszolgálati- és Tankönyvkiadó, Budapest, 2014.

Finszter Géza: Rendészettan, Dialóg Campus Kiadó, Budapest, 2018.

Friedmann, Robert R.: Közrendészet: néhány elméleti és gyakorlati megfontolás. Belügyi Szemle, 34 (1996/6) 114-123.

Korinek László: Rendszerváltozás a belügyben, Belügyi Szemle, 63 (2015/1) 5-33.

Korinek László: Nomádok és letelepedettek - gondolatok a közösségi bủnmegelőzésröl, Jogtudományi Közlöny, 61 (2006/7-8) 247-267.

Kovács István: Vezetési funkciók egy helyi rendvédelmi szerv életében - célmeghatározás, vagyis a feladatok kitüzésének, és tisztázásának folyamata, Rendőrségi Tanulmányok, 1 (2018/3) 119-136. DOI: https://doi.org/10.3311/ope.308

Kovács Gábor - Czuprák Ottó: A szervezetvezetés elmélete, Budapest, Dialóg Campus, 2017.

Salgó László: Centralizáció és decentralizáció kérdései a magyar rendőrség szervezetében, Új Rendészeti Tanulmányok, (1995/1)

\section{Jogi források}

1997. évi XV. törvény A Helyi Önkormányzatok Európai Chartájáról szóló, 1985. október 15-én, Strasbourgban kelt egyezmény kihirdetéséről

2011. évi CLXXXIX. törvény Magyarország helyi önkormányzatairól

2012. évi CXX. törvény az egyes rendészeti feladatokat ellátó személyek tevékenységéről, valamint egyes törvényeknek az iskolakerülés elleni fellépést biztosító módosításáról

115/2003. OGY határozat a bünmegelőzés nemzeti stratégiájáról

57/2013. (XII. 21.) ORFK utasítás az általános rendőrségi feladatok ellátására létrehozott szervtevékenység-irányítási központjai, egyes rendőri szervek ügyeletei, valamint a segélyhívásokat fogadó központok egységes müködéséről

26/2015. (XII. 9.) ORFK utasítás a körzeti megbízotti szabályzatról

\section{Internetes források}

A decentralizáció fogalma, www.kislexikon.hu/decentralizacio_decentralizalas.html (Letöltve: 2019. 07. 22.)

Közösségi Rendészeti Projekt, 2016, www.police.hu/hu/a-rendorsegrol/europai-tamogatasok/egyeb-forrasok/kozossegi-rendeszeti-projekt (Letöltve: 2019. 11. 13.) 